\title{
Przebaczenie pod lupą Służba Bezpieczeństwa wobec listu Episkopatu Polski z 10 lutego $1966 \mathrm{r}$.
}

\author{
opracowanie Radosław Ptaszyński
}

prawa tzw. Orędzia biskupów polskich do biskupów niemieckich, która wybuchła w listopadzie 1965 r., to moment szczególnego napięcia w relacjach między państwem a Kościołem w okresie PRL. List, który realnie był szczególnym „progiem historii” w stosunkach między Polakami i Niemcami, wyprzedzał swoją epokę, w społeczeństwie polskim nie spotkał szczególnego zrozumienia. Żywa nadal wojenna trauma, czasem wrogość, nie powodowały również masowych aktów solidarności z polskimi biskupami. Wejście hierarchów na pole spraw międzynarodowych, do którego monopol przyznawała sobie wyłącznie autorytarna władza, oraz przekonanie o nieprzychylnym nastawieniu do Niemców większości społeczeństwa były powodami do rozpętania jednej z największych kampanii propagandowych tamtego czasu¹. Te tendencje zaczęły się zmieniać, gdy skala ataków na Kościół przybrała gigantyczne

1 Szerzej o Orędziu: 18 listopada 1965, Watykan. Orędzie biskupów polskich do ich niemieckich braci w Chrystusowym urzędzie pasterskim, [w:] P. Raina, Kardynał Wyszyński, t. 6: Orędzie Biskupów a reakcja władz, Warszawa 1995, s. 19-28, 362; P. Madajczyk, Przebaczamy i prosimy o przebaczenie, „Więź” 1990, nr 9, s. 112-124; E. Czaczkowska, Rola kardynała Stefana Wyszyńskiego w powstaniu orędzia biskupów polskich do niemieckich. Nieznane dokumenty w Archiwum Prymasa Polski, „Przegląd Zachodni” 2016, nr 3 (360), s. 193-203; P. Madajczyk, Okoliczności powstania Orędzia biskupów polskich do biskupów niemieckich, [w:] Wokół Orędzia. Kardynał Bolesław Kominek - prekursor pojednania polsko-niemieckiego, red. W. Kucharski, G. Strauchold, Wrocław 2009, s. 109-119; tenże, Na drodze do pojednania. Wokót orędzia biskupów polskich do biskupów niemieckich z 1965 roku, Warszawa 1994; T. Gajowniczek, Urząd do spraw Wyznań wobec kościelnych prób pojednania polsko-niemieckiego w latach 1965-1966, [w:] Studia i szkice politologiczne. W kręgu problemów polskiej polityki, red. J. Filipkowski i in., Olsztyn 2011, s. 39-49. 
rozmiary i gdy stało się jasne, że list jest jedynie pretekstem do prowadzonej od wielu lat walki z Kościołem. Istotnym problemem był trwający do początku 1966 r. powszechny brak znajomości całości listu oraz brak wykładni jego treści ze strony hierachów. Próżnię tę wypełniała wydana przez władzę broszura z podaniem argumentów strony rządowej. Szerszą reakcją Kościoła, próbą doprecyzowania używanych w Orędziu sformułowań, był przytaczany poniżej list Episkopatu Polski z 10 lutego 1966 r., czytany w kościołach 6 marca² Tekst precyzował użyte w Orędziu sformułowania, w tym wyjaśniał, że słowa o przebaczeniu zostały wypowiedziane jedynie w imieniu katolików ${ }^{3}$. Ogłoszenie listu i jego powszechne odczytanie było ściśle nadzorowane przez Służbę Bezpieczeństwa. $Z$ tego względu prezentowany poniżej dokument rzuca nieco światła co do skali, zarówno odczytania samego listu, jak i inwigilacji.

Duszpasterzom i wiernym oraz wszystkim ludziom dobrej woli braterskie pozdrowienie w Panu przesyłamy ${ }^{4}$.

My Biskupi Kościoła Chrystusowego, do których przede wszystkim odnoszą się słowa „Idąc, nauczajcie”, poczuwamy się do obowiązku przemówić do Was, którzy wspólnie z nami jesteście Ludem Bożym, w okolicznościach szczególnej wagi dla życia Kościoła oraz dla uwydatnienia jego jedności ${ }^{5}$.

Kościół Katolicki przeżywał w ciągu ostatnich lat na Soborze Watykańskim II wielkie sprawy Boże. Sobór był nie tylko największym wydarzeniem w ostatniej dobie dla samego Kościoła, ale zdołał poważnie zainteresować całe chrześcijaństwo, a nawet w jakiejś mierze - cały świat. I w naszym społeczeństwie widzieliśmy również niezwykłe zainteresowanie sprawami Soboru i ofiarny udział duchowy w nim Wiernych. Należało się spodziewać, że uwaga nasza po zakończeniu obrad będzie jeszcze mocniej skierowana w stronę tych wartości i nowych treści, które zrodziły się na Soborze z Ducha Św. I z naszych wysiłków.

Ale takie jest już prawo ludzkiej świadomości, że zawsze najmocniej zalega to w niej, co najnowsze i ostatnie. Zaraz po Soborze zaszły w naszym społeczeństwie rzeczy nowe, które ostro przeszły przez świadomość Polaków i odbiły się

2 P. Sroka, Kardynał Bolesław Kominek i Orędzie biskupów polskich do biskupów niemieckich w oczach wrocławskich kleryków, [w:] Wokót Orędzia..., s. 160.

${ }^{3}$ Ł. Kamiński, Władze PRL i społeczeństwo polskie wobec Orędzia biskupów polskich, [w:] Wokół Orędzia..., s. 136.

${ }^{4}$ Podkreślenie w tekście.

5 Podkreślenie w tekście. 
głośnym echem w świecie. Wyrosła sprawa o treści religijnej, soborowa i ekumeniczna w swym charakterze, a równocześnie sprawa nasza, polska, millenijna. Zrodziła się ona na tle naszego listu, skierowanego do biskupów z obydwu państw niemieckich, listu, który był jednym wśród 56 wysłanych do Biskupów katolickich w całym świecie z okazji Tysiąclecia Chrztu Polski.

Zdajemy sobie sprawę z ogromnego znaczenia, jakiego nabrał nasz list na przestrzeni minionych tygodni i miesięcy, jak błogosławione są owoce i skutki, które dotychczas zrodził nie tylko dla naszego narodu, ale także dla odprężenia niepokojących napięć sąsiedzkich w naszym rejonie europejskim.

List nasz spotkał się w opinii międzynarodowej z bardzo wysoką oceną moralną nie tylko kół katolickich, ale i protestanckich oraz wszystkich ludzi dobrej woli, aż do niektórych kręgów komunistycznych i ateistycznych włącznie.

Opinia całego świata kulturalnego wyraża Biskupom polskim najwyższe uznanie za ich chrześcijańską i pasterską odwagę, nazywając ich list do Biskupów niemieckich jednym z najważniejszych dokumentów pokojowych ${ }^{6} \mathrm{w}$ chwili obecnej. Nazywa go również dokumentem, który śmiało wyciąga praktyczne wnioski z uchwał soborowych i świadczy o żywej obecności Kościoła w świecie współczesnym. List nasz znajduje się jak najbardziej w orbicie pokojowych wysiłków Ojca św. Pawła VI, podjętych w najczystszej intencji niesienia światu pomocy duchowej i moralnej.

Rozumiemy, że wszystkie elementy naszej sąsiedzkiej przeszłości polsko-niemieckiej z minionych wieków, a zwłaszcza pełne grozy i potworności ostatnie przeżycie wojenne, wzmogły niezwykłe zainteresowanie Listem, z którym zwróciliśmy się do katolickich biskupów i ich wiernych w krajach niemieckich. Zainteresowanie to ogarnęło w naszej Ojczyźnie szerokie kręgi społeczeństwa. Dlatego uważamy za swój doniosły obowiązek zwrócić się z tymi słowami do wszystkich, którzy na nie oczekują?.

Wyrażamy naszym Braciom Kapłanom wdzięczność za jedność duchową, jaką z nami zachowali. Wiernym katolikom wyrażamy słowa uznania za godną i ufną postawę. Tym braciom niewierzącym, zespolonym z nami w człowieczeństwie i umiłowaniu Ojczyzny, którzy poważnie szukają prawdy i umieją rozpoznawać dobre intencje, wyrażamy szczere pozdrowienia, nie pamiętając tego, co niektórzy w pierwszym porywie i zaognieniu mówili i czynili.

Wśród polemiki, która powstała wokół najpoważniejszych zagadnień, chęć sama nie zawsze była utrzymywana na należytym poziomie, wysunęły się na czo-

${ }^{6}$ Podkreślenie w tekście.

7 Podkreślenie w tekście. 
ło sprawy, do których trzeba teraz powrócić, gdy mija napięcie uczuć nieopanowanych; pozwala to bowiem na spokojne spojrzenie prawdzie w oczy. Rozważmy:

1. Stosunek biskupów polskich do naszych granic.

2. Pytanie, $\mathrm{w}$ czyim imieniu przemawialiśmy oraz

3. Wielki problem, który zamknięty został w słowach: „Przebaczamy i prosimy o przebaczenie".

\section{Zagadnienie granic i dobra ojczyzny}

Nie możemy nawet przypuszczać, my biskupi polscy, aby w społeczeństwie polskim mógł ktoś poważnie myślący pomówić nas o zdradę Ojczyzny i jej żywotnych interesów. Dlatego mimo, iż podobnie uwłaczające nam zarzuty rzucono pod naszym adresem w prasie, młodzieży w niektórych szkołach, a pracownikom na wielu zebraniach, nie czujemy się wewnętrznie zmuszeni do odpierania ich. Tysiącletnie dzieje Polski katolickiej pokazują, że duchowieństwo z biskupami na czele, było zawsze przepojone duchem zdrowego patriotyzmu i umacniało go Ojczyźnie.

Gdy chodzi o nas, którzy na waszych oczach żyjemy i pracujemy, Wy sami możecie ocenić bezstronnie nasze postępowanie. Praca nasza jest tego rodzaju, że buduje największe wartości w Narodzie, a przez to umacnia organizację państwową, bo zmierza do wychowania człowieka w poczuciu obowiązków obywatelskich.

Wiemy dobrze, że dla całego Narodu sprawa terytorium Ojczyzny jest warunkiem samej egzystencji państwa. Nigdy nie poddawaliśmy pod dyskusję sprawy naszych granic na Odrze i Nysie, uważając stan naszego obecnego posiadania za „być albo nie być” naszego państwa. Daliśmy temu dobitny wyraz wielokrotnie, a zwłaszcza ostatnio, obchodząc uroczystości, związane z XX-leciem naszej organizacji kościelnej na Ziemiach Zachodnich.

List nasz do biskupów niemieckich uważamy za dalszy ciąg wypowiedzi Olsztyńskich i Wrocławskich. Tak też był oceniony przez wytrawnych mężów stanu całego świata. Ból duchowy, który musieliśmy przeżyć, dołączamy bez protestu do naszego biskupiego krzyża. Wyrażamy równocześnie zadowolenie, że w pewnym momencie zdrowy sąd wziął górę nad uprzedzeniem i że czynniki miarodajne przestały nas posądzać o antynarodowe i sprzeczne $z$ interesami państwa poczynania. Jest to jedyne rozsądne stanowisko dla polskiej racji stanu, która bez szkody nie może wmawiać wszystkim dookoła, że są przeciwnikami obecnego stanu posiadania Polski.

\section{W czym imieniu przemawialiśmy?}

Stawiano pytania, z różnym nastawieniem umysłu i woli, w czyim imieniu Piszą polscy biskupi, a przede wszystkim w czyim imieniu przebaczają i w czyim imie- 
niu proszą o przebaczenie. Nie przemawialiśmy z pozycji nauk historycznych', bo nie takie jest zadanie Listu. Pragnęliśmy przede wszystkim przypomnieć biskupom niemieckim nasze dziejowe powiązania na przestrzeni 1000 lat - powiązania, których raczej nie nam, Polakom, wstydzić się potrzeba - by następnie w słowach poważnych przypomnieć im krzywdy, których doznał nasz Naród. W odpowiedzi otrzymaliśmy uznanie tej bolesnej - prawdy w liście biskupów niemieckich. Niepotrzebnie więc doszukuje się krytyka w liście pasterskim, czystej historycznej metody. Nasze milczenie o związkach kulturowych ze wschodem jest uzasadnione. Gdybyśmy pisali list do biskupów prawosławnych poruszylibyśmy to we właściwym miejscu.

Nie występowaliśmy w imieniu społeczeństwa, ani w imieniu Narodu, w sensie świeckim i politycznym. Chociaż bowiem naród polski jest w absolutnej większości katolicki i wyraża swą przynależność do Kościoła, to jednak my Biskupi, nie uważamy sę tym samym za politycznych przywódców Narodu. Inne jest nasze powołanie. Jesteśmy przedstawicielami Kościoła Chrystusowego w narodzie Polskim i nasze prawo przedstawicielstwa sięga tak daleko, jak daleko narodowy duch polski jest wewnętrznie zrośnięty z poczuciem przynależności do Kościoła Katolickiego.

Przemawialiśmy, jako przedstawiciele społeczności katolickiej w narodzie polskim, a prawo do głosu wzięliśmy z naszego posłannictwa do Chrystusa, z posługiwania, jakie w Kościele spełniamy. Prawo do przemawiania wzięliśmy z wiary i wierności Was wszystkich, to znaczy tych, którym chcemy służyć nie mądrością polityczną, nie budowaniem tego, czy innego ustroju, ale pokazywaniem drogi do Chrystusa. A ponieważ droga do Chrystusa wiedze przez życie powszednie, dlatego sprawy codziennego życia zawsze mają swoje moralne połączenie ze sprawą zbawienia i domagają się wprowadzenia porządku Chrystusowego, który jest ładem Mądrości i łaski Bożej. Niech więc nikt z tych, którzy nie poczuwają się do żywej łączności ze wspólnotą katolicką, nie sądzi, że przemawialiśmy w jego imieniu. Zresztą biskupi polscy są obywatelami Narodu, i jako tacy mają prawo i obowiązki równe wszystkim innym obywatelom.

\section{Powiedzieliśmy: „przebaczamy i prosimy o przebaczenie”.}

Byliśmy niemal wszyscy świadkami ludobójstwa, które przed laty przewaliło się przez naszą ziemię. Większość ówczesnych Biskupów i kapłanów polskich przeszła przez obozy koncentracyjne, więzienia i różne udręki. Mówimy do społeczeństwa, które to wszystko pamięta i do młodych, którym przypomina się te

8 Podkreślenie w tekście.

9 Podkreślenie w tekście. 
straszne rzeczy. Nie dziwimy się więc, że tak wielkie poruszenie nastąpiło po naszym słowie: przebaczamy. Nie dziwimy się, ale równocześnie prosimy o przemyślenie raz jeszcze spokojnym umysłem tej sprawy.

Nie mamy zamiaru poruszać - choć po apostolsku bardzo byśmy tego pragnęli - tych, którzy mierzą wszystko jedynie własną ludzką miarą. Zwracamy się do ludzi wierzących w to, że Jezus Chrystus, który żył na ziemi, jest odwieczną mądrością Boga, jest samym Bogiem i Prawodawcą. Zwracamy się do tych, którzy wierzą Chrystusowym słowom. A Chrystus zapowiada, że przynosi ludzkości nowe prawo. Jego prawo jest trudne: „Przykazanie nowe daję wam, abyście się wzajemnie miłowali"10 (Jan 13, 34). W zakresie prawa miłości znajduje się najtrudniejszy element: prawo, którego nie ma w żadnej innej religii, prawo, które wydaje się na ludzki sposób trudne do zachowania: prawo miłości nieprzyjaciół: „Miłujcie waszych nieprzyjaciół, dobrze czyńcie tym, którzy was nienawidzą"11 (Mat. 5, 44). Dla wielu wydaje się to sprzeczne z porządkiem ludzkiego myślenia, zwłaszcza jeżeli myślenie ich obraca się jedynie w ramach doczesności i wyklucza pomoc łaski w wykonywaniu każdego dobra, a zwłaszcza dobra najtrudniejszego. Ale prawo to jest warunkiem nadziei, jest bodźcem wszelkich wysiłków ku postępowi społecznemu i rozwiązywaniu niepokonalnych zda się przeciwności.

Wierni Chrześcijanie. Zdawaliśmy najtrudniejszy egzamin z naszego sposobu myślenia wobec sumienia, wobec Kościoła Powszechnego, wobec ludzkości, nawet wobec całego świata. Niech każdy z nas odpowie sobie sam, jak przez tę próbę ogniową przeszedł? Czy zdolny jest myśleć i oceniać sprawy po chrześcijańsku? Nasza wiara musi niekiedy przechodzić wewnętrzne próby w naszym prywatnym życiu, musi też stać się „widowiskiem dla ludzi i aniołów” - jak mówi Pismo Święte.

Obserwujemy, jak przez dzisiejszy świat idzie kryzys sztywnych, kodeksowych, ludzkich miar. Miary te okazują się niewystarczające dla rozwiązania spraw społecznych, tym więcej - konfliktów międzynarodowych. Tam gdzie zawodzą kodeksy, gdzie urzędowe czynniki nie mogą dojść do porozumienia i są bezsilne, tam - poza oficjalną polityką i wojną - pragną dojść do przemienia ludzie dobrej woli, poczuwając się ponad granicami językami i ustrojami do wspólnoty wielkiej Rodziny człowieczej. Ogromnie przyczynił się do odkrycia tego zjawiska, które będzie decydować o przyszłości - niezapomniany papież Jan XXIII. Ojciec św. Paweł VI prowadzi to dzieło energicznie naprzód: nie lęka się stanąć nawet na forum Organizacji Narodów Zjednoczonych, gdzie wszystkie narody świata przyjęły Go z uznaniem i ulgą.

10 Podkreślenie w tekście.

11 Podkreślenie w tekście. 
To również mieliśmy na myśli, pisząc do Biskupów i katolików niemieckich. Chcieliśmy im powiedzieć, że jeśli po tysiącu lat przeważnie dla nas ciężkich i przykrych, mamy żyć jako sąsiedzi, może się to stać jedynie na drodze wzajemnego zrozumienia, zawartego nie w kodeksach, ale w sumieniu i duszy Narodów, zwłaszcza tych, co należą do Kościoła Katolickiego.

Mieliśmy chrześcijańską odwagę wykazać jasno społeczności niemieckiej, jej grzechy wobec naszej społeczności narodowej. Sadzimy, że nasze oskarżenie było równocześnie wezwaniem do pokuty i zmiany sposobu myślenia na przyszłość. Wyraziliśmy słowa przebaczenia dla tych, którzy winę swoją rozumieją i mają dobrą wolę pokojowego współżycia z nami, którzy rozumieją, że ziemie jakie posiadamy i w trudzie zagospodarowujemy, są nie tylko z dawna naszą ojcowizną piastowską, ale są też koniecznością dla naszej egzystencji. Przebaczaliśmy tak, jak przebaczył Chrystus na Krzyżu, a przez tajemnicę Krzyża przebaczył wszystkim: i nam, którzy do Was mówimy i Wam, którzy nas słuchacie. Chrystus Pan nam przebaczył i przebaczać będzie do ostatniej chwili naszego życia.

Powiedzieliśmy: „i prosimy o przebaczenie” ${ }^{12}$.

Czy Naród polski ma powód do tego by prosić swych sąsiadów o przebaczenie? Zapewne, nie. Jesteśmy przekonani, że nawet gdyby jeden, jedyny Polak okazał się człowiekiem niegodnym, gdyby jeden jedyny w ciągu historii spełnił czyn niegodny, już mielibyśmy powód do wyrażenia: „przepraszamy”, jeżeli chcemy być narodem ludzi szlachetnych i wielkodusznych; narodem lepszej przyszłości.

Znamy postać dobrego papieża Jana, zwanego „proboszczem świata”, który po całym szlachetnym życiu, kończąc wśród cierpień swoje dni, ofiarował cierpienia za wszystkich i nieustannie wszystkich za najmniejsze uchybienie swego życia przepraszał.

Na początku Wielkiego Postu staje przed nami wyraźniej sylwetka Krzyża i bliższe stają się nam rany cierpiącego Jezusa. Zachciejmy nauczyć się czegośs w myśleniu i działaniu z Ran Jezusowych, z których zrodziło się prawo miłości i przebaczenie; ono z kolei przyniosło ulgę całej ludzkości. Wchodząc w wielkopostne rozmyślania w roku, kończącym okres Wielkiej Nowenny a równocześnie w roku kończącym 1000-letnie dzieje naszego związku z Krzyżem Chrystusowym, wejdźmy na wzgórze Golgoty i zobaczymy stojącą tam Maryję, Bolesną matkę Jezusa. Stojąc pod Krzyżem w pobliżu Jej osoby, w duchowym zjednoczeniu z Maryją, może lepiej i łatwiej pojmiemy Królestwo Boże w nas i w powołaniu

12 Podkreślenie w tekście.

13 Podkreślenie w tekście. 
Narodu. Wtedy też pełniej zrozumiemy prośbę modlitwy pańskiej: „Odpuść nam nasze winy, jako i my odpuszczamy..." 14 .

W całym Narodzie Polskim, który przeżywa swoje 1000-lecie niech zapanuje pokój Chrystusowy i budująca zgoda, te niezbędne warunki radosnego świętowania millenijnego, podstawą naszej chrześcijańskiej narodowej przyszłości.

Błogosławieństwo Wszechmogącego Boga Ojca, Syna i Ducha Świętego niech zstąpi na Was, na całą Ojczyznę i pozostanie z Wami. Amen

Dane na Konferencji Episkopatu Polski w Warszawie dnia 10 lutego, Millenijnego Roku 1966.

Podpisani wszyscy biskupi polscy obecni na Konferencji.

Ministerstwo Spraw Wewnętrznych Departament IV Warszawa 7 III 1966 r

L. S. Ug-0853/1/66

Tajne

Informacja 56/IV/66

Dotyczy: czytanego w kościołach w dniu 6 III 1966 r. komunikatu episkopatu w sprawie orędzia ${ }^{15}$.

W dniu 6 III 66 r. w kościołach na terenie kraju odczytywano wiernym komunikat episkopatu zawierający kolejną próbę obrony hierarchii. W większości kościołów komunikat został odczytany bez komentarzy. Nie stwierdzono większego zainteresowania zarówno faktem, jak i treścią komunikatu.

W związku z odczytywanym komunikatem episkopatu pt. „Duszpasterzom i wiernym oraz wszystkim ludziom dobrej woli braterskie pozdrowienia w panu przesyłamy", Służba bezpieczeństwa zabezpieczyła dopływ informacji z 3.567 kościołów. W rezultacie tego stwierdzono, że komunikat odczytany został w 3.216 kościołach, tj. 90\% poddanych sprawdzeniu.

Komunikat przeczytano w całości w 3.105, a w skrócie w 111 przypadkach. Komunikatu nie czytano w 351 kościołach. Stwierdzono również, że w 156 kościołach księża uzupełniali, bądź komentowali komunikat, lecz tylko

14 Podkreślenie w tekście.

15 Podkreślenie w tekście. 
w 5 przypadkach pozytywnie (szczegółowe zestawienie zawiera załącznik do niniejszej informacji).

$\mathrm{Na}$ podstawie uzyskanych informacji o przebiegu odczytywania komunikatu przez księży można stwierdzić, iż kler parafialny odniósł się do tego dokumentu dość obojętnie, czego wyrazem jest względnie mała ilość wrogich komentarzy, znacznie niższa niż ilość przypadków nieodczytywania.

Charakterystyczny jest również fakt małego zaangażowania się biskupów w tej sprawie. Na 21 wygłoszonych kazań do treści komunikatu nawiązali tylko

- bp. Zaręba wygłosił dwa kazania w katedrze wrocławskiej; kazania zawierały ataki skierowane przeciwko władzom i propagandzie państwowej (jedyne wystąpienie zawierające bezpośrednio wrogie akcenty). Zaremba krytykował m.in. środki informacji masowe, a zwłaszcza prasę i radio, mówiąc, że „środki przekazywania myśli winny być wykorzystywane do mówienia prawdy, a nie do szkalowania biskupów”. Dowodził o mylnym poglądzie tych, którzy występując przeciwko biskupom mniemają, że w wyniku tych ataków wierni opuszczą hierarchię. Oświadczył, że szkaluje się również papieża Piusa XII twierdzeniami o sprzyjaniu Niemcom. „Są jednakże na to dowody, że papież ten zawsze występował za Polską katolicką".

W drugim wystąpieniu powtórzył w zasadzie powyższe treści kazania z katedry, podkreślając w zakończeniu, że „kościół w Polsce nie będzie zniszczony, ponieważ Chrystus na to nie pozwoli”.

- bp. Bednorz, występując w miejscowości Kubliniec, woj. katowickie, powiedział m.in. „historia oceni kto ma rację w sprawie orędzia, władze państwowe czy biskupi”. Dowodził, że polscy biskupi dobrze przysłużyli się Polsce i byli godnymi ambasadorami swojego narodu. Stwierdził też, że „kościół zawsze służy narodowi i spełnia pozytywną rolę”. Wspomniał, jakoby za granicą coraz liczniejsze były głosy sugerujące celowość przyznania polskim biskupom pokojowej nagrody Nobla. 


\section{Komentarze i wypowiedzi kleru ${ }^{16}$}

Komentarze, którymi Książa czytający komunikat poprzedzali, bądź uzupełniali teść odczytywanego dokumentu episkopatu, w zasadzie nie zawierają nowych treści. Komentarze dotyczą ogólnie rzecz biorąc obrony autorów orędzia, do czego wykorzystywano następujące argumenty:

- kampania propagandowa wokół orędzia jest wyrazem walki państwa z kościołem i duchowieństwem; w tej sytuacji trzeba się modlić za kościół i biskupów;

- biskupi są ludźmi światłymi i wiedzą co czynią, dlatego wolno im zajmować się polityką, tym bardziej, że na przestrzeni historii biskupi nigdy nie zdradzili narodu;

- kampania wokół orędzia zawiera oszczerstwa rzucane na biskupów $i$ jest to możliwe na skutek tego, że wierni nie zrozumieli dobrze istoty orędzia;

- orędzie ma na celu obronę pokoju; trzeba w tej sprawie wierzyć biskupom, ponieważ są oni patriotami. Prasa natomiast naświetla sprawę orędzia tendencyjnie i fałszywie;

- nagonka na biskupów sieje niezgodę w narodzie;

- komunikat episkopatu jest odpowiedzią na wszystkie wiece, masówki, zebrania itp.

Biskupi niemieccy uznali winy popełnione przez Niemców wobec narodu polskiego, natomiast inni sąsiedzi do win i krzywd, które nam wyrządzili, nie przyznają się;

- biskupi polscy prosili Niemców o przebaczenie bo po wojnie wielu Polaków szabrowało i rabowało, a niekiedy nawet zabijało bezbronnych Niemców.

Stwierdzono też nieliczne wypowiedzi kleru w rodzaju:

- wszyscy robią błędy, więc i biskupi mają do tego prawo, dlatego trzeba im wybaczyć to, że wysłali list do Niemców, prosząc o przebaczenie;

- jeden zbłądził, a wszyscy muszą to usprawiedliwiać i ponosić konsekwencje;

16 Podkreślenie w tekście. 
- wydanie komunikatu przez episkopat w spawie orędzia zaostrzy i tak już napięte stosunki między kościołem a państwem, co nic dobrego nie wróży dla Kościoła.

\section{Komentarze i wypowiedzi osób świeckich ${ }^{17}$}

Nie stwierdzono u wiernych większego zainteresowania treścią odczytywanego komunikatu w sprawie orędzia. Notowano przypadki wychodzenia ludzi z kościołów w trakcie czytania, co doprowadziło w kilku przypadkach do przerwania odczytywania tego dokumentu.

Uzyskane informacje wydają się wskazywać, że u wiernych wyraźnie zmalało zainteresowanie dla kościelnych dokumentów w sprawie orędzia, zawierających próby tłumaczenia się hierarchii. Wskazują na to uchwycone wypowiedzi i komentarze osób świeckich w rodzaju:

- komunikat dowodzi, iż biskupi nadal tłumaczą się przed opinią publiczną;

- komunikatem biskupi próbują usprawiedliwić się w opinii wierzących;

- prasa musiała mieć rację, skoro biskupi tak bardzo tłumaczą się;

- duchowieństwo, w tym także hierarchia, winni zająć się pracą duszpasterską, a nie polityką;

- informacje episkopatu nic nowego nie wnoszą i nie wyjaśniają wielu spraw niezrozumiałych dla prostego człowieka;

- komunikat i orędzie pokazały prawdziwe oblicze polskiego episkopatu.

Stwierdzono też w bardzo nielicznych przypadkach głosy bagatelizujące akcję propagandową w związku z orędziem.

R.K./S.K.

17 Podkreślenie w tekście. 


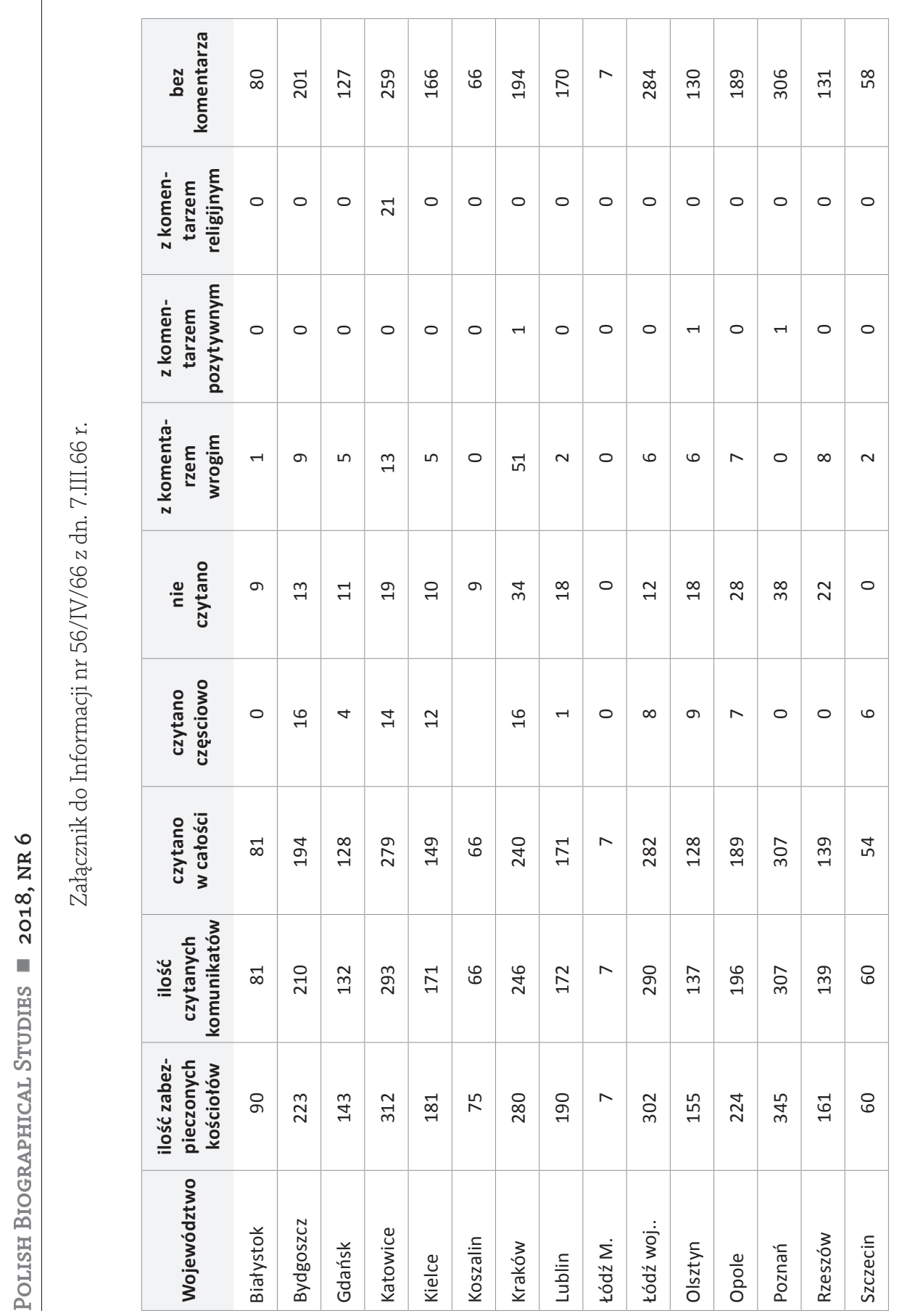




\begin{tabular}{|c|c|c|c|c|c|}
\hline 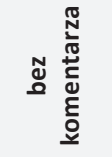 & $\stackrel{d}{\sim}$ & $\stackrel{\infty}{\infty}$ & $\underset{\sim}{\stackrel{\infty}{\rightarrow}}$ & 욱 & م̂m \\
\hline 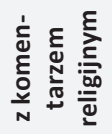 & $N$ & 0 & 0 & 0 & $\stackrel{\sim}{\sim}$ \\
\hline 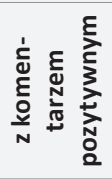 & 0 & $N$ & 0 & 0 & in \\
\hline 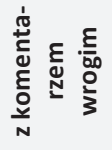 & $\exists$ & $\stackrel{\text { 号 }}{\circ}$ & $r$ & $m$ & 곡 \\
\hline.$\frac{0}{\stackrel{0}{\frac{c}{\pi}}}$ & $m$ & $\stackrel{0}{N}$ & 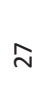 & $\nabla$ & 鬲 \\
\hline 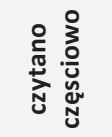 & $m$ & 0 & $\stackrel{m}{\sim}$ & $N$ & $\underset{\neg}{\stackrel{G}{二}}$ \\
\hline 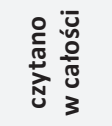 & 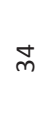 & 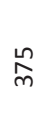 & $\underset{\sim}{\stackrel{+}{*}}$ & $\stackrel{\sim}{\infty}$ & $\begin{array}{l}\text { 兄 } \\
\text { m }\end{array}$ \\
\hline 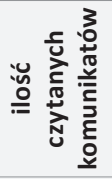 & $\hat{m}$ & 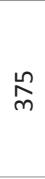 & $\underset{\sim}{\infty}$ & $\underset{\exists}{\stackrel{-}{-}}$ & $\underset{\sim}{\stackrel{\sim}{N}}$ \\
\hline 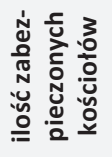 & \& & ㄱํㅁ & $\stackrel{\vec{N}}{\sim}$ & $\underset{\exists}{\stackrel{\sim}{二}}$ & $\begin{array}{l}\hat{\omega} \\
\stackrel{n}{n}\end{array}$ \\
\hline $\begin{array}{l}0 \\
3 \\
\frac{1}{0} \\
0 \\
3 \\
00 \\
0 \\
3\end{array}$ & $\begin{array}{l}\sum_{0} \\
\sum_{0} \\
\pi \\
N \\
N \\
N \\
3\end{array}$ & $\begin{array}{l}\dot{0} \\
3 \\
0 \\
0 \\
0 \\
N \\
N \\
\frac{0}{\pi} \\
3\end{array}$ & $\begin{array}{l}3 \\
\frac{\pi}{4} \\
0 \\
\vdots \\
3\end{array}$ & 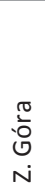 & 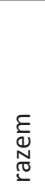 \\
\hline
\end{tabular}

